\title{
Evaluation of the Aggressiveness of Different Multi-Axle Loads using APT Tests
}

\author{
J.-P. Kerzrého, P. Hornych, A. Chabot, S. Trichet, T. Gouy, and G. Coirier \\ UNAM Université, IFSTTAR, F-44341 Bouguenais, France - Contact : pierre.hornych@ifsttar.fr
}

L. Deloffre

Laboratoire Régional des Ponts et Chaussées de Strasbourg, 11 Rue Jean Mentelier, F-67035 Stras-

bourg Cedex , France France

ABSTRACT: This paper presents results of a full scale accelerated test performed on the IFSTTAR pavement fatigue carrousel, to study the effect of various multiple axle combinations on bituminous pavements. The tested combinations correspond to the permissible maximum loads in France for the following axle systems: tridem axle $(255 \mathrm{kN})$, tandem axle with dual wheels $(210 \mathrm{kN})$, tandem axle with single wheels $(170 \mathrm{kN})$ and single axle with dual wheels $(130 \mathrm{kN})$. Recently, however, the French road carriers' federation was authorized to change the vehicle load from $400 \mathrm{kN}$ to $440 \mathrm{kN}$. The consequences of this increase are also discussed. The test was performed on two thick bituminous pavement sections consisting of a 16-cm granular subbase and a 26-cm thick bituminous layer. Both pavements were instrumented with strain gages, vertical displacement and temperature sensors. The objective of this research is to compare the strain signals and the maximum strain levels obtained for different axle combinations and temperature conditions and then, to compare the results with classical pavement design calculations to assess the relative aggressiveness of the different axle systems. The fatigue life of the two pavements, however, was not studied because, owing to their thickness, too many load cycles would were necessary to complete a full fatigue test.

\section{INTRODUCTION}

In France, transport of goods is currently divided up as $78 \%$ by road, $16 \%$ by waterway $5 \%$ by rail and $1 \%$ by pipeline or air. In order to absorb the expected traffic growth, the government is developing rail transport, which is considered safer and less polluting. To limit the number of heavy trucks, some Northern European countries have authorized alternatives including trains of loaded motor trucks, called ecocombis or EMS (European Modular Systems). They can haul up to 60 tons of goods, but can only be used for long distance transport and are considered more dangerous regarding traffic safety. In France, the search for a balanced transport policy was marked by the recent decision to increase vehicle maximum loads from 40 to 44 tons without modification regarding the number of axles of the vehicles. This concerns mostly five to six axle heavy goods vehicles carrying cereals, aggregates or liquids.

The impact of this gross weight legislation change on roads is not very well understood. Calculations were performed, using the French pavement design method (SETRA-LCPC 1994, Corté \& Goux, 1996) which is based on a simplifying hypotheses (linear elastic behaviour, pavement design criteria based on maximum tensile strain values), but until now the problem has not been studied experimentally. This paper presents some first experimental studies, carried out on the circular test track at IFSTTAR Nantes, to compare the aggressiveness of the following different axle systems: tandem axle with single wheels, tandem axle with dual wheels, tridem axle with single wheels and single axle with dual wheels. The study was conducted to examine the performance of two thick bituminous pavements, for heavy traffic, under the above applied axle combinations adjusted to current permissible maximum loads. The pavements were instrumented with strain gages, vertical displacement sensors and temperature sensors, placed at different depths. The number of load cycles applied during this test was not sufficient to damage the thick structures. Pavement deformation and vertical displacement measurements, on the other hand, were used to assess the aggressiveness of the different axle systems.

\section{PAVEMENT STRUCTURES AND LOAD COMBINATIONS}

\subsection{The circular test track facility}

The IFSTTAR accelerated pavement testing facility, in Nantes (Autret et al. 1987, Gramsammer et al. 1999, IFSTTAR) is an outdoor circular carrousel 
dedicated to full-scale pavement experiments carried out with public and private partners (Figure 1). The carrousel is a one thousand horse-power electrohydraulic facility, with a central tower and four 20-m long arms, which can run at a maximum speed of $100 \mathrm{~km} /$ hour. The experimental site includes three test rings, with the facility being moved from one ring to another in approximately one week.

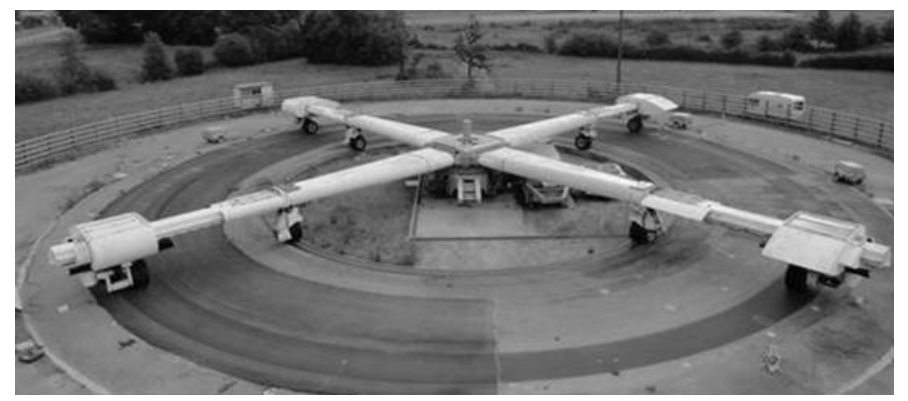

Figure 1. View of the IFSTTAR pavement testing facility

Each arm can be equipped with different load combinations. The half-axle loads can vary from $40 \mathrm{kN}$ on a single wheel to $135 \mathrm{kN}$ on a triple axle system with single wheels, a tandem axle with dual wheels or a tandem axle with single wheels.

\subsection{Studied loads}

The different axle load combinations studied are presented in Figure 2. All combinations conform to the current permissible maximum loads per axle or group of axles in the French road regulations.

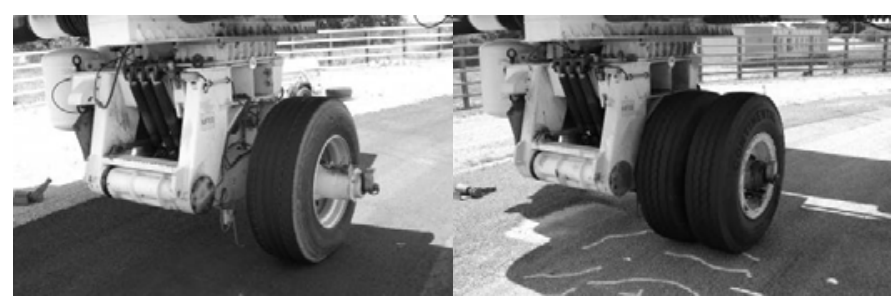

Single wheel - load $42.5 \mathrm{kN}$

Dual wheels - load $65 \mathrm{KN}$

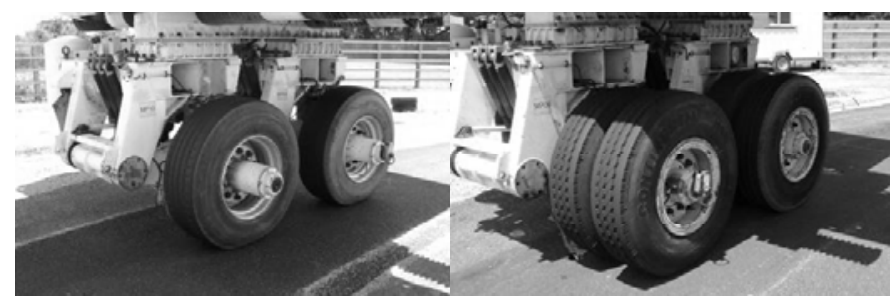

Tandem axle with single

Tandem axle with dual wheels - load 2 x $42.5 \mathrm{kN}$

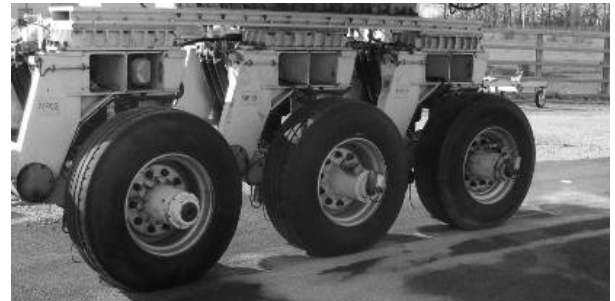

Tridem axle with single wheels - load 3 x $42.5 \mathrm{kN}$

Figure 2 . The circular test track facility equipped with the different axle systems studied.
During the tests, a lateral wandering of the loads is applied, over a width of approximately $1.10 \mathrm{~m} \mathrm{(11}$ different lateral positions), with a Gaussian distribution over this width. The strain gages are always placed in the centre of the wheel path (Position 6).

\subsection{Tested pavement structures and instrumentation}

The tested pavements were thick bituminous structures commonly used for the construction of heavy traffic roads (Figure 3). Structure 1 is used for freeways with a traffic capacity of TC5-30 according to the French Catalogue of Pavement Structures (between 6 and 14 million heavy trucks over 30 years). Structure 2 is used for main or secondary roads with a traffic capacity of TC3-20 (between 0.5 and 1.5 million heavy trucks over 20 years). Both pavements were instrumented with strain gages, vertical displacement and temperature sensors during construction of the circular test track, to measure response under different load combinations. The location of the different instruments within each structure is presented in Figure 3.

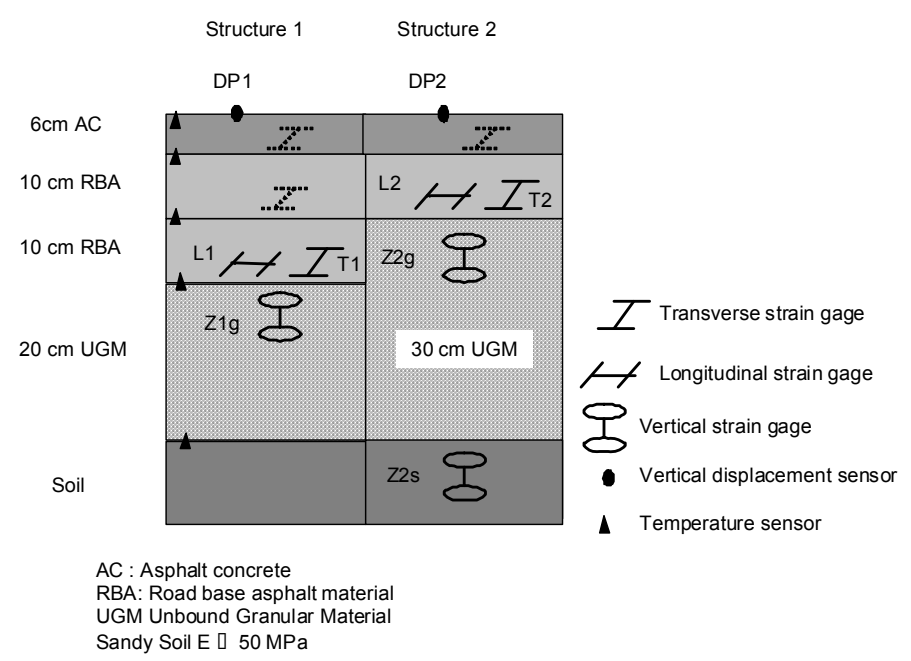

Figure 3. Instrumentation of the experimental pavements.

The clay sand of the subbase contains approximately $10 \%$ water sensitive fines. The Unbound Granular Material (UGM) is a $0 / 31.5-\mathrm{mm}$ crushed gneiss, classified as B according to French standards. The composition of the bituminous materials is presented in Table 1.

Table 1. Bituminous mix compositions.

\begin{tabular}{lcc}
\hline \multicolumn{1}{c}{ Fractions } & AC (class 2) (\%) & RBA (Class 3) (\%) \\
\hline $0 / 2$ & 34 & 35 \\
$2 / 6$ & 16 & 20 \\
$6 / 10$ & 49 & 10 \\
$10 / 14$ & - & 35 \\
Filler & 1 & - \\
Bitumen 35/50 & 5.7 & 4.6 \\
\hline
\end{tabular}

Complex modulus tests on trapezoidal specimens (NF EN 12 697-31) were performed on the two bituminous mixes. The standard elastic moduli ob- 
tained for the two materials at $15^{\circ} \mathrm{C}$ and $10 \mathrm{~Hz}$ were respectively $11,320 \mathrm{MPa}$ and $10,700 \mathrm{MPa}$. The results of these tests were interpreted with the HuetSayegh visco-elastic model (Huet 1963, 1999, Sayegh 1965, Chailleux et al. 2006), and the model parameters obtained for the two mixes are summarized in Table 2.

Table 2. Huet Sayegh's model parameters obtained for the two bituminous mixes.

\begin{tabular}{lccccc}
\hline & E0 $(\mathrm{MPa})$ & $\begin{array}{c}\text { Einf } \\
(\mathrm{MPa})\end{array}$ & $\delta$ & $\mathrm{k}$ & $\mathrm{h}$ \\
\cline { 2 - 4 } AC & 20.0 & 29843 & 2.194 & 0.217 & 0.658 \\
RBA & 20.0 & 22980 & 1.985 & 0.174 & 0.578 \\
\hline \multicolumn{5}{c}{} \\
\cline { 1 - 4 } AC & A0 & A1 & A2 & & \\
\cline { 2 - 4 } RBA & 20.0 & 29843 & 2.194 & & \\
\cline { 2 - 4 } & 20.0 & 22980 & 1.985 & & \\
\hline
\end{tabular}

The two pavement structures were instrumented with vertical strain gage sensors placed in the subgrade and the UGM, and horizontal strain gages placed at the bottom of the bituminous layers. Figure 4 shows the different gages used. An anchored vertical displacement sensor was also installed in each structure to record the vertical displacement of the pavement surface (vertical deflection). Finally, temperature sensors were placed at different depths in each structure to combine mechanical measurements with material temperature data (Figure 3).

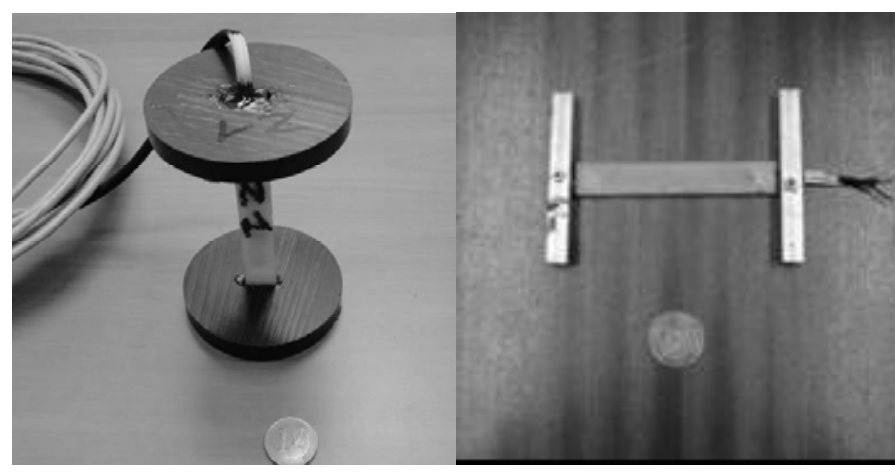

Figure 4. Strain gages used for vertical and horizontal strain measurements.

\subsection{Axle load configurations}

The experiment was conducted in two successive phases, with different axle load combinations mounted on the four arms of the circular test track (Figure 5). The loads applied on the different groups of axles are summarized in Table 3 and correspond to the maximum permissible loads of the French road regulation.

These types of loads correspond to typical axle configurations of heavy trucks. Tridem axles with single wide wheels are those most commonly found on heavy trucks with a gross vehicle weight of 40 tons. The single wheel mounted on a single axle is never used at the rear of heavy vehicles, but only as the front axle, with a lower axle load around
$70 \mathrm{kN}$. During the test, this axle was loaded at $42.5 \mathrm{kN}$ and used as a reference load. The objective of the research was to examine the effects, on the same sensors, of the four axle systems loaded at the maximum permissible load and to compare the results with those of the single reference wheel. Since the carrousel has only four arms, two successive configurations were used to complete the test.

Table 3. Current permissible maximum loads per axle or group of axles.

\begin{tabular}{lc}
\hline \multicolumn{1}{c}{ Axle type } & $\begin{array}{c}\text { Maximum load per } \\
\text { axle }(\mathrm{kN})\end{array}$ \\
\hline Dual wheels & 130 \\
Tandem axle with dual wheels & 210 \\
Single wide wheel & 85 \\
Tandem axle with single wide wheels & 170 \\
Tridem axle with single wide wheels & 255 \\
\hline
\end{tabular}
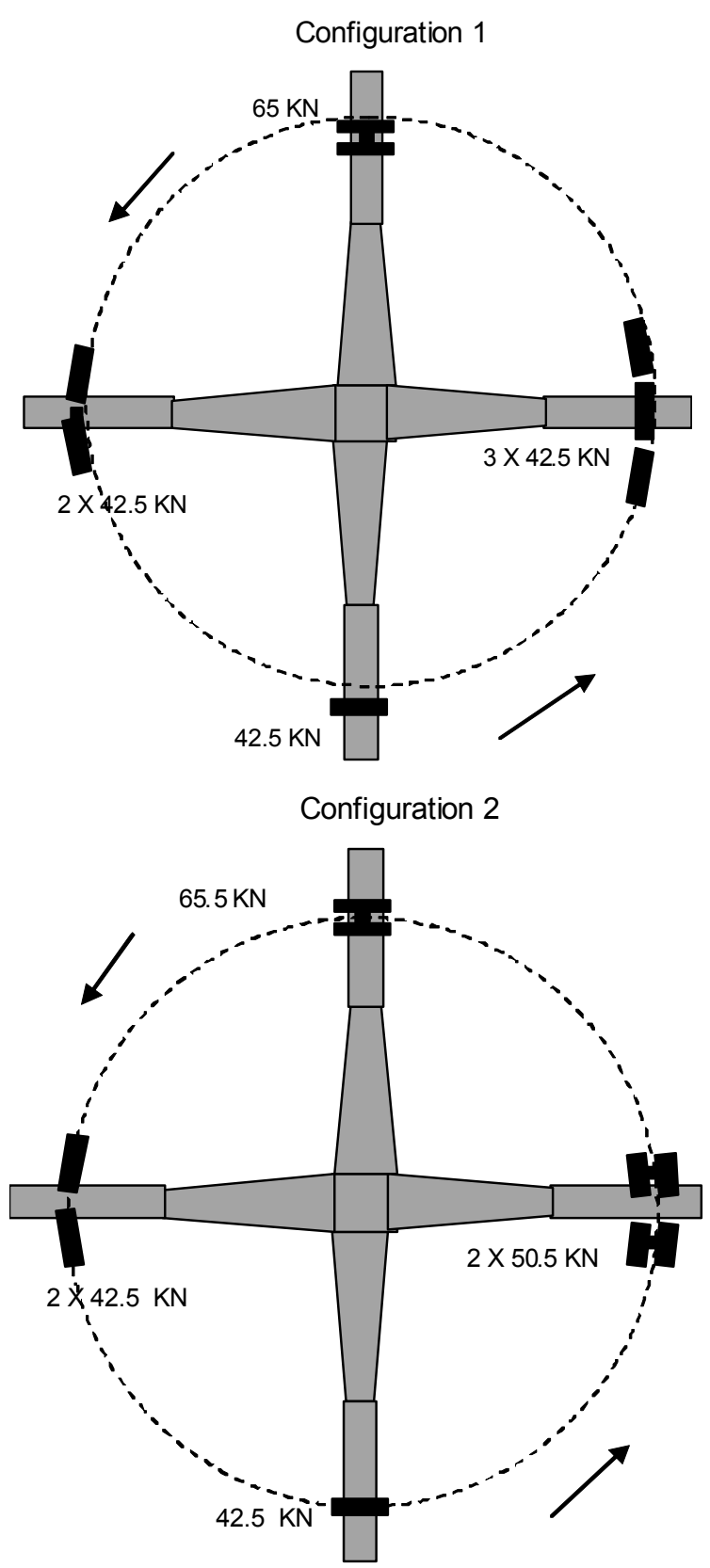

Figure 5. The two successive axle system configurations of the test. 
The tires chosen for the test were:

- Dunlop 385/65 R 22.5 tires for single wide wheels, inflated at 8.5 bars.

- Dunlop 12.00 R20 SP321 tires for dual wheels, inflated at 8.5 bars.

Tire imprints were determined under a load of $65 \mathrm{kN}$ for the dual wheels and $42.5 \mathrm{kN}$ for the single wheel (Figure 6). They can be approximated by rectangles, loaded with a mean vertical pressure of $0.62 \mathrm{MPa}$ and $0.66 \mathrm{MPa}$ respectively.

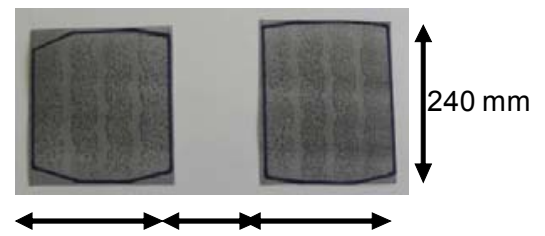

$225 \mathrm{~mm} \quad 145 \mathrm{~mm} \quad 225 \mathrm{~mm}$

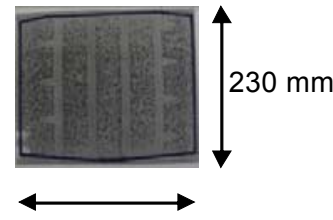

$290 \mathrm{~mm}$
Figure 6. Dual and single wheel imprints at $\mathrm{F}=65 \mathrm{kN}$ and $\mathrm{F}=$ $42.5 \mathrm{kN}$, respectively.

\section{EXAMPLES OF MEASUREMENT RESULTS}

\subsection{Mechanical stiffness of the pavement structures}

The mechanical response of the tested pavements in terms of typical pavement surface deflection values and mean tensile strain values at the bottom of the bituminous materials obtained under the application of the reference load (single wheel loaded at $42.5 \mathrm{kN}$ ) are plotted in Table 4 (tensile strain values are positive).

Table 4. Maximum deflection and deformation values under a single wheel load of $42.5 \mathrm{KN}$.

(speed $\mathrm{v}=42 \mathrm{~km} / \mathrm{h}$, mean temperature $\mathrm{T}=20^{\circ} \mathrm{C}$ )

\begin{tabular}{lcc}
\hline & Structure 1 & Structure 2 \\
\hline $\begin{array}{l}\text { Vertical displacement at } \\
\text { the surface of the pave- }\end{array}$ & $0.32 \mathrm{~mm}$ & $0.45 \mathrm{~mm}$ \\
$\begin{array}{l}\text { ment } \\
\begin{array}{l}\text { Longitudinal strains at the } \\
\text { bottom of the bituminous } \\
\text { base layer }\end{array}\end{array}$ & $+90 \mu$ strain & $+150 \mu$ strain \\
$\begin{array}{l}\text { Transverse strains at the } \\
\text { bottom of the bituminous } \\
\text { base layer }\end{array}$ & $+120 \mu$ strain & $+300 \mu$ strain \\
\hline
\end{tabular}

Note that the transverse strains are higher than the longitudinal strains. The strain signals, presented below, also show that visco-elastic effects are more visible on the transverse strain gages.

\subsection{Examples of strain signals under the tridem axle load}

Figures 7 to 10 present examples of strain signals and displacement signals recorded as the tridem axle load (42.5 kN for each wheel) travels on both pavement structures. The distance between the wheels is $1.38 \mathrm{~m}$ for all the tandem and tridem combinations studied. The influence of the wheelbase on material deformations, though recognized, was not studied.

The signals were recorded under the centre of the wheels at a speed of $42 \mathrm{~km} / \mathrm{h}$ and with a mean temperature within the bituminous materials of $18^{\circ} \mathrm{C}$.

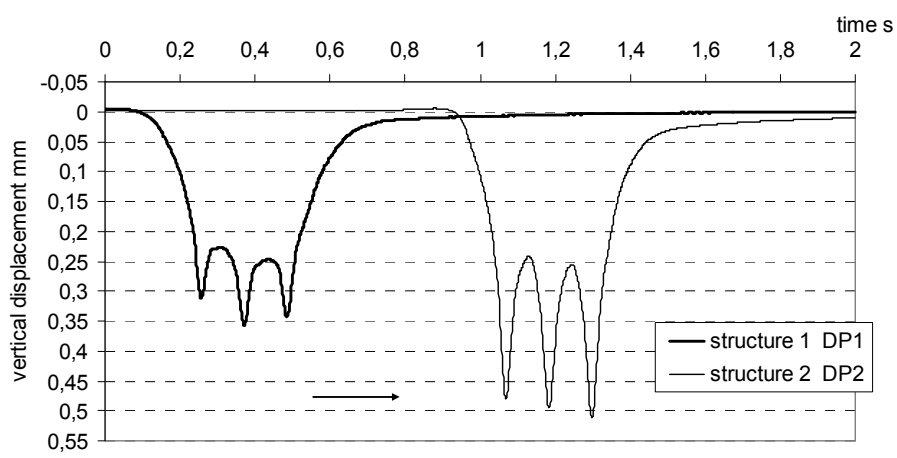

Figure 7. Vertical displacement signals at the pavement surface under tridem axle load.

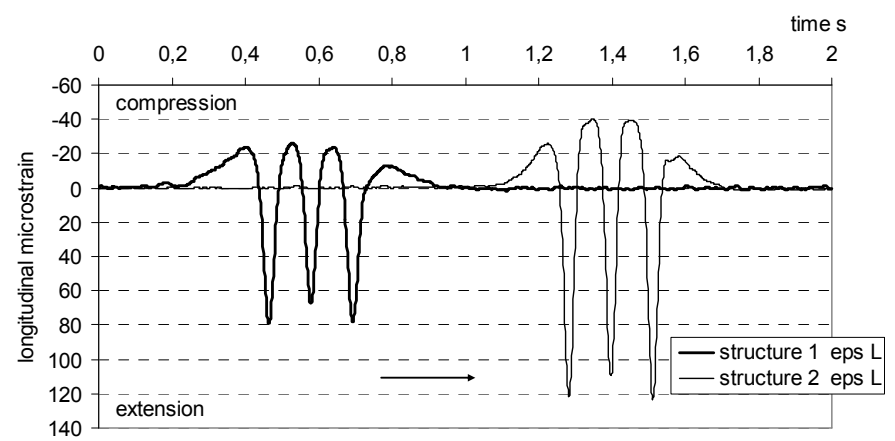

Figure 8. Longitudinal strain signals at the bottom of the bituminous materials under tridem axle load.

The signals from the longitudinal strain gages placed at the bottom of the bituminous layers always return to zero (Figure 8). The transverse strain gage signals distinctly reveal the viscoelastic behaviour of the materials (Figure 9): the strains tend to cumulate under the passage of the three wheels, and the return to the zero state is slow. Some permanent deformation can sometimes be observed, in particular at high temperatures or low speeds. The transverse strains are in all cases greater than the longitudinal strains.

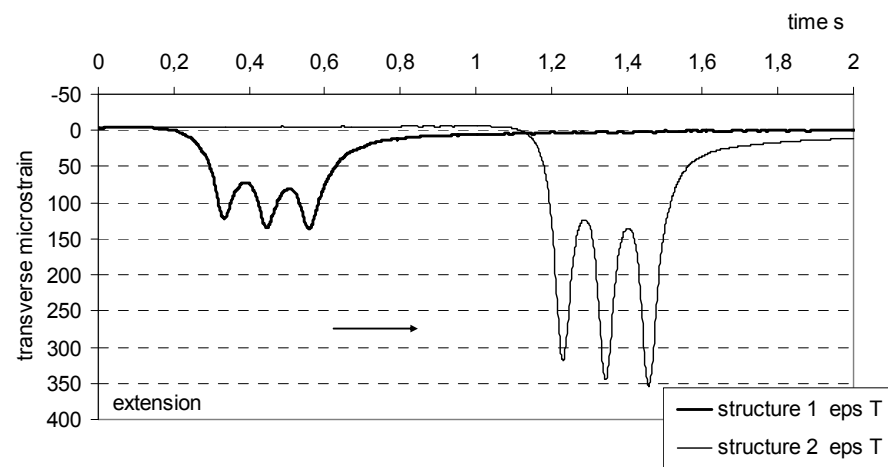

Figure 9. Transverse strain signals at the bottom of the bituminous materials under tridem axle load. 


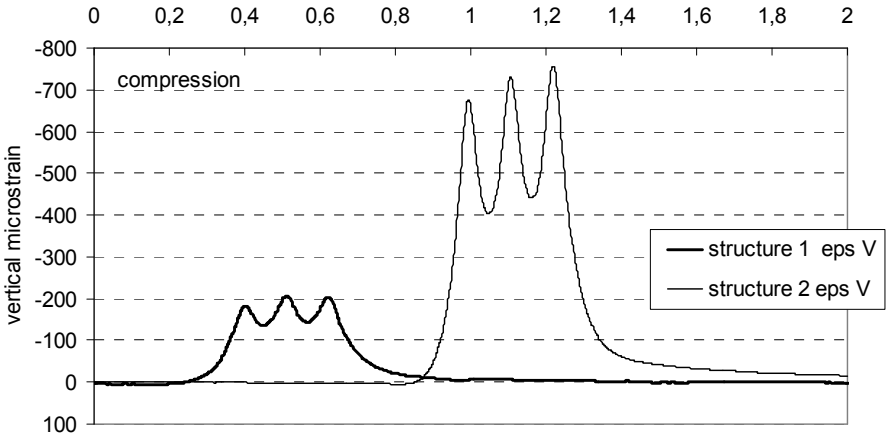

Figure 10. Vertical strain signals at top of the UGM, under tridem axle load.

\section{COMPARISON OF PAVEMENT RESPONSE UNDER DIFFERENT AXLE COMBINATIONS}

\subsection{Normalization of measurements recorded at different temperatures}

Figures 11 and 12 present, for Structure 1, the maximum transverse strain values measured at different depths in the bituminous layers, at two different temperatures $\left(9^{\circ} \mathrm{C}\right.$ and $\left.30^{\circ} \mathrm{C}\right)$, under the single wheel load, for the eleven transverse positions of the wheel, due to the lateral wandering. The strain distributions change considerably with temperature. For instance, at the bottom of the bituminous base layer, under the centre of the wheel, the maximum transverse strains are about four times higher at $30^{\circ} \mathrm{C}$ than at $9^{\circ} \mathrm{C}$. This demonstrates the high sensitivity to temperature of the response of bituminous pavements and underlines the difficulty of comparing strain measurements recorded under different axle load combinations at different temperatures.

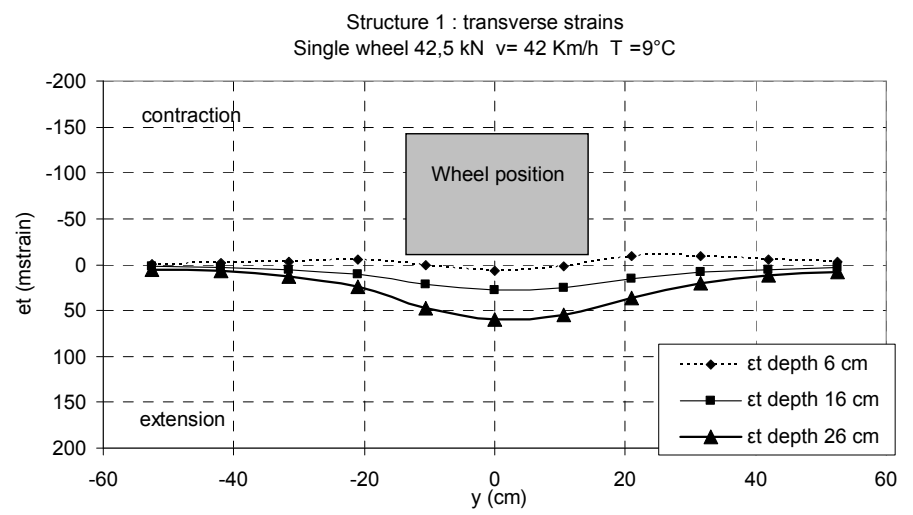

Figure 11. Maximum transverse strains under the reference single wheel load $(42.5 \mathrm{kN})$ for different lateral positions temperature $9^{\circ} \mathrm{C}$.

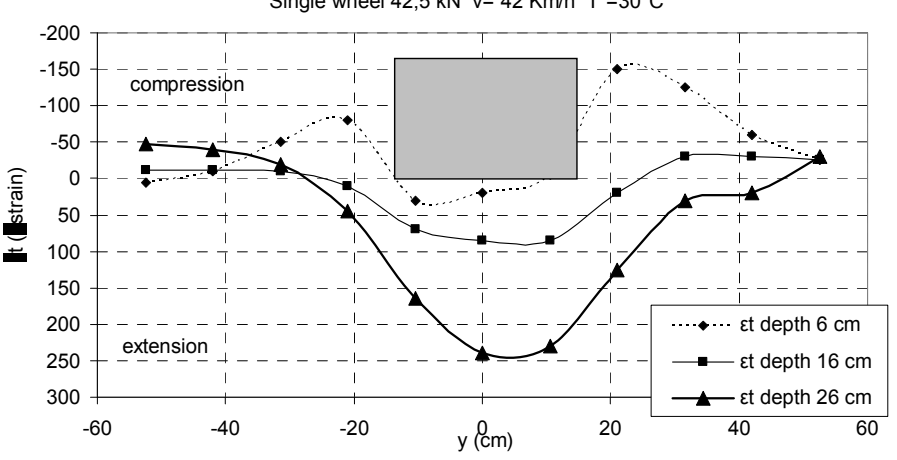

Figure 12. Maximum transverse strains under the reference single wheel load $(42.5 \mathrm{kN})$ for different lateral positions temperature $30^{\circ} \mathrm{C}$.

Because of the visco-elastic, thermo susceptible behaviour of bituminous materials, the recorded strain levels are highly dependent on temperature and loading speed. In this study, all the tests were performed at a constant speed of $42 \mathrm{~km} / \mathrm{h}$. (i.e., 7 revolutions/minute for loads running on the $19 \mathrm{~m}$ radius track). To eliminate the effect of temperature variations when comparing the effect of different axle systems, the maximum strain or displacement values obtained under different multiple axle loads were normalized by dividing them by the values obtained under the reference single wheel, at the same temperature (measurements carried out simultaneously).

\subsection{Comparison between the different axle load combinations and the single reference wheel}

As previously explained, two successive configurations were necessary to complete the test and compare the effects of the four multiple axle load combinations with those of the single $42.5 \mathrm{kN}$ reference wheel. In both configurations, the reference wheel was mounted on one arm of the carrousel. The relative effect of the different axle combinations was assessed by calculating the ratio of the maximum strain values recorded by the sensors under multiple axle loads to those obtained under the reference single wheel.

The strain or displacement ratios $\mathrm{R}$ are thus defined by:

$\mathrm{R}=$ maximum strain under multiple axle load /maximum strain under single wheel load.

The approach for the calculation of the ratios $\mathrm{R}$ is illustrated in Figure 13. These ratios represent a simplification, because they only take into account the maximum strain level, and not the duration of the load signal, which is higher for a tridem axle than for a single axle. 


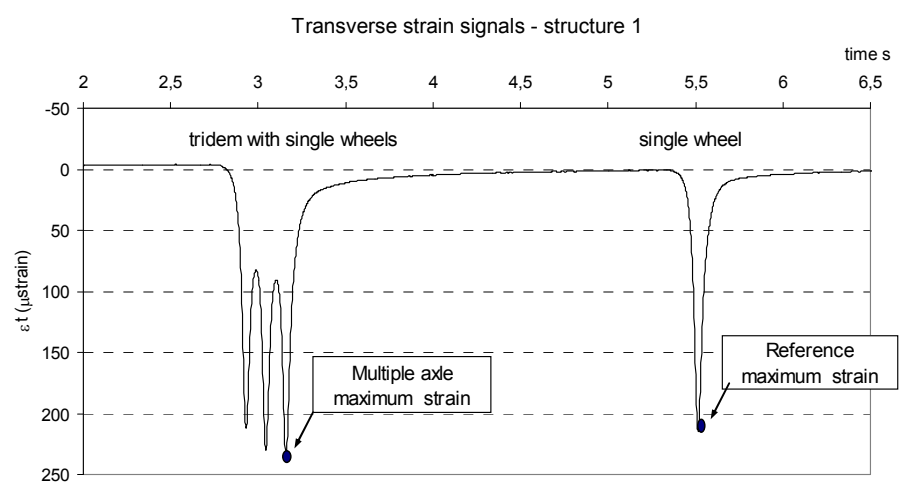

Figure13. Example of determination of the maximum strain ratio $\mathrm{R}$ from measured strain signals (here $\mathrm{R}=1.14$ ).

The mean values of strain or displacement ratios $\mathrm{R}$ obtained for the different axle load combinations are summarized in Tables 5 and 6 . These mean $\mathrm{R}$ values result from measurements made at different temperatures, varying between $10^{\circ} \mathrm{C}$ and $40^{\circ} \mathrm{C}$. They were calculated for the two pavement structures, for the following sensors (Figure 3):

- Vertical displacement sensors (noted DP1 and DP2)

- Vertical strain gages placed at the top of the UGM layer, (noted Z1g and Z2g)

- Vertical strain gages placed at the top of the subgrade Z2s (only for structure 2).

- Longitudinal strain gages placed at the bottom of the bituminous base layer (noted L1 and L2)

- Transverse strain gages placed at the bottom of the bituminous base layer (noted T1 and T2)

Table 5. Structure 1: ratio $\mathrm{R}$ of the maximum strain recorded under multiple axle loads to that obtained under the reference single wheel load.

\begin{tabular}{lccccc}
\hline & \multicolumn{4}{c}{ Axle loads } \\
\cline { 2 - 5 } Measurement & $\begin{array}{c}42.5 \mathrm{kN} \\
\text { single }\end{array}$ & $\begin{array}{c}65 \mathrm{kN} \\
\text { dual }\end{array}$ & $\begin{array}{c}2 \times 42.5 \mathrm{kN} \\
\text { tandem single }\end{array}$ & $\begin{array}{c}3 \times 42.5 \mathrm{kN} \\
\text { tridem single }\end{array}$ & $\begin{array}{c}2 \times 52.5 \mathrm{kN} \\
\text { tandem dual }\end{array}$ \\
\hline Vertical displacement DP1 & 1 & 1.25 & 1.16 & 1.26 \\
Vertical strain Z1g & 1 & 1.29 & 1.13 & 1.23 & - \\
Longitudinal strain L1 & 1 & 1.25 & 0.91 & 0.97 \\
Transverse strain T1 & 1 & 0.95 & 1.13 & 1.25 \\
\hline
\end{tabular}

Table 6. Structure 2: ratio $\mathrm{R}$ of the maximum strain recorded under multiple axle loads to that obtained under the reference single wheel load.

\begin{tabular}{|c|c|c|c|c|c|}
\hline \multirow[b]{2}{*}{ Measurement } & \multicolumn{5}{|c|}{ Axle loads } \\
\hline & $\begin{array}{c}42.5 \mathrm{kN} \\
\text { single }\end{array}$ & $\begin{array}{c}65 \mathrm{kN} \\
\text { dual }\end{array}$ & $\begin{array}{c}2 \times 42.5 \mathrm{kN} \\
\text { tandem single }\end{array}$ & $\begin{array}{c}3 \times 42.5 \mathrm{kN} \\
\text { tridem single }\end{array}$ & $\begin{array}{c}2 \times 52.5 \mathrm{kN} \\
\text { tandem dual }\end{array}$ \\
\hline Vertical displ.DP2 & 1 & 1.25 & 1.08 & 1.13 & 1.20 \\
\hline Vertical strain Z2s & 1 & 1.26 & 1.08 & 1.13 & 1.13 \\
\hline Vertical strain Z2g & 1 & 1.12 & 1.06 & 1.14 & 1.18 \\
\hline Longitudinal strain L2 & 1 & 1.11 & 0.95 & 0.98 & 1.06 \\
\hline Transverse strain T2 & 1 & 0.93 & 1.08 & 1.10 & 0.98 \\
\hline
\end{tabular}

The results are similar for the two structures. In terms of the relative effect (strains) of the different axle combinations, compared with the reference single wheel, it can be concluded that:

- For the vertical deflection, and the vertical strains at the top of the subgrade, the tandem and tridem axles with $42.5 \mathrm{kN}$ wheels are more aggressive than the single $42.5 \mathrm{kN}$ wheel (the strains increase, due to interaction between the wheels). The most aggressive configuration is the single axle with dual wheels, with $65 \mathrm{kN}$ load.

- For the transverse strains at the bottom of the bituminous layers, the tandem and tridem axles with single wheels are again, more aggressive than the single $42.5 \mathrm{kN}$ wheel. The dual wheels, on the contrary, are less aggressive, in terms of transverse strains, than the single wheel.

- For the longitudinal strains at the bottom of the bituminous layers, the results are opposite to those obtained for the transverse strains: the strains are lower under tandem and tridem axles than under the single $42.5 \mathrm{kN}$ wheel. The most aggressive configuration is the single axle with dual wheels, loaded at $65 \mathrm{kN}$

These results indicate that, depending on the strain criterion (or design criterion) considered, the same axle configuration is not always the most aggressive. In terms of vertical strain, and longitudinal tensile strain, the single axle with dual wheels was the most aggressive. However, the tridem axle was the most aggressive in terms of the transverse tensile strain (but the ratios $\mathrm{R}$ do not indicate whether longitudinal or transverse tensile strain was highest).

It should be added that these results were obtained for a given wheelbase $(1.38 \mathrm{~m})$ and given tire type. For tandem and tridem axles, a smaller wheelbase could lead to a higher aggressiveness (for tridem axles, the minimum wheelbase is about $1.12 \mathrm{~m})$. 


\section{MODELLING OF THE MULTIPLE AXLE LOADS}

The experimental results obtained on the test track were compared with pavement calculations, performed using two different models:

- A classical multi-layer linear elastic model, implemented in the software ALIZE (IFSTTAR).

- The software VISCOROUTEC 2.0 (Chabot et al. 2010, Duhamel 2005), based on a multi-layer visco-elastic model.

ALIZE is a pavement design software tool developed by IFSTTAR, based on the French pavement design method, and using a classical multi-layer linear elastic model developed by Burmister. VISCOROUTEC 2.0 is a software tool developed for the modelling of pavements with visco-elastic layers, under moving wheel loads. It is based on the HuetSayegh visco-elastic model, which effectively describes the behaviour of bituminous materials.

The two models were used for the two pavement structures, but due to space limitations, only the results obtained on Structure 1 are presented in this paper. Similar assumptions were used for both models:

- The thickness of the layers was equal to the real thickness measured on the pavement by levelling.

- The moduli of the unbound granular layer and subgrade were defined by back-calculation, from deflection tests, performed during and after construction.

- The comparisons were made for a series of measurements performed on the test track at an average temperature of $20^{\circ} \mathrm{C}$, and a loading speed of $42 \mathrm{~km} / \mathrm{h}$.
- The properties of the bituminous layers were determined from laboratory complex modulus tests. With VISCOROUTEC 2.0, the calculations were made with the Huet-Sayegh model parameters of the materials (Table 2), and a loading speed of $42 \mathrm{~km} / \mathrm{h}$.

- With ALIZE, the calculations were made with values of elastic modulus determined using the Huet Sayegh model, for the temperature and frequency of the tests $\left(20^{\circ} \mathrm{C}, 6 \mathrm{~Hz}\right)$. This led to elastic moduli of $8,808 \mathrm{MPa}$ for the wearing course bituminous concrete and 7,321 MPa for the road base asphalt.

- The loads were simulated by rectangular areas loaded by a uniform vertical pressure (Figure 6).

Figures 14 to 17 present comparisons between the longitudinal strains $\varepsilon_{1}$ and transverse strains $\varepsilon_{\mathrm{t}}$ measured at the bottom of the asphalt layers, and the modelling results, for four different load combinations. The maximum strain values are presented in Table 7.

Table 7. Comparison of maximum measured and calculated tensile strains at bottom of bituminous layers under the different axle combinations

\begin{tabular}{|c|c|c|c|c|c|}
\hline Method & Strain & $\begin{array}{c}42.5 \mathrm{kN} \\
\text { single }\end{array}$ & $\begin{array}{c}65 \mathrm{kN} \\
\text { dual }\end{array}$ & $\begin{array}{c}42.5 \mathrm{kN} \\
\text { tandem } \\
\text { single }\end{array}$ & $\begin{array}{c}42.5 \mathrm{kN} \\
\text { tridem } \\
\text { single } \\
\end{array}$ \\
\hline \multicolumn{6}{|c|}{ Measured ( $\mu$ strain) } \\
\hline Gage L1 & $\varepsilon_{l}$ & 89.7 & 116.2 & 83.8 & 91.0 \\
\hline Gage T1 & $\varepsilon_{\mathrm{t}}$ & 115.9 & 108.7 & 135.1 & 144.7 \\
\hline \multicolumn{6}{|c|}{ Predicted ( $\mu$ strain $)$} \\
\hline \multirow{2}{*}{ ALIZE } & $\varepsilon_{l}$ & 83.6 & 104.2 & 73.3 & 69.4 \\
\hline & $\varepsilon_{\mathrm{t}}$ & 80.3 & 75.0 & 88.6 & 97.3 \\
\hline VISCO- & $\varepsilon_{1}$ & 75.0 & 100.2 & 69.1 & 60.5 \\
\hline ROUTE & $\varepsilon_{\mathrm{t}}$ & 96.1 & 84.7 & 124.3 & 136.6 \\
\hline
\end{tabular}

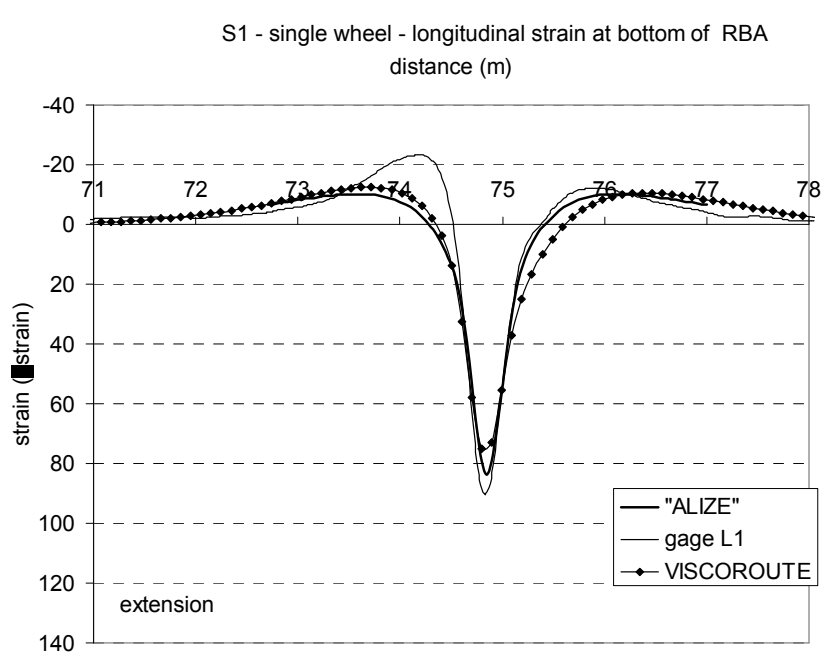

Figure 14. Structure 1 - comparison of measured and calculated strains under single wheel load. 

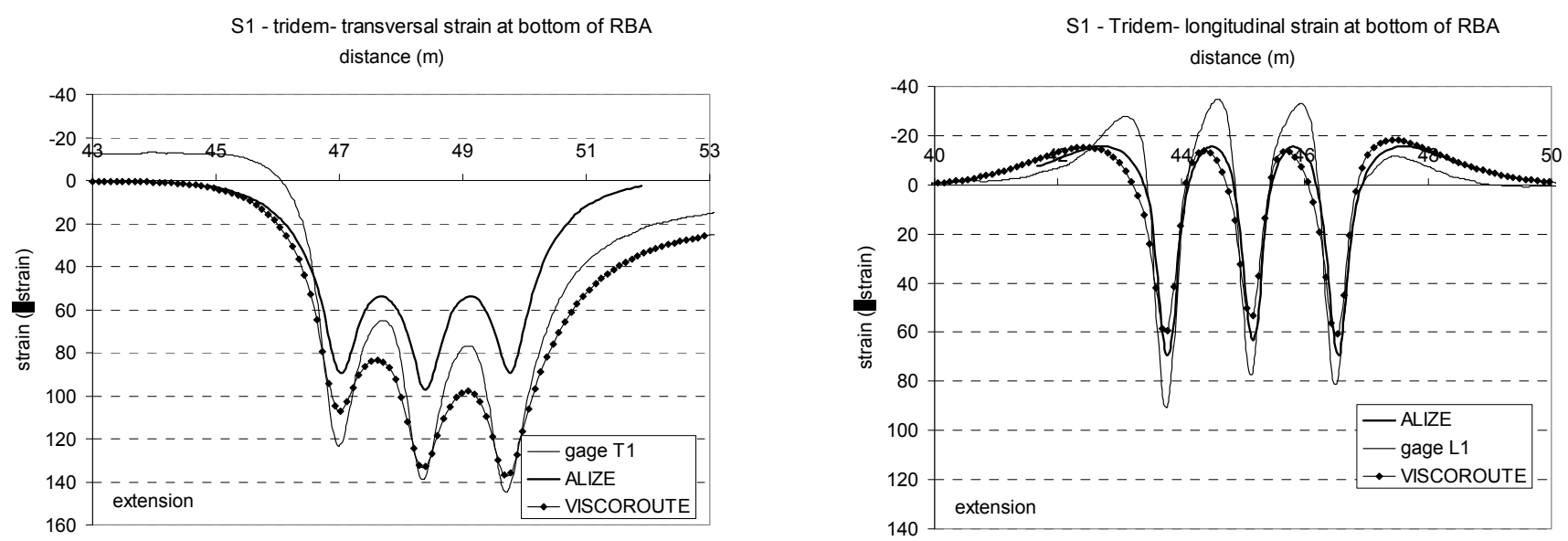

Figure 15. Structure 1 - comparison of measured and calculated strains under tridem axle.
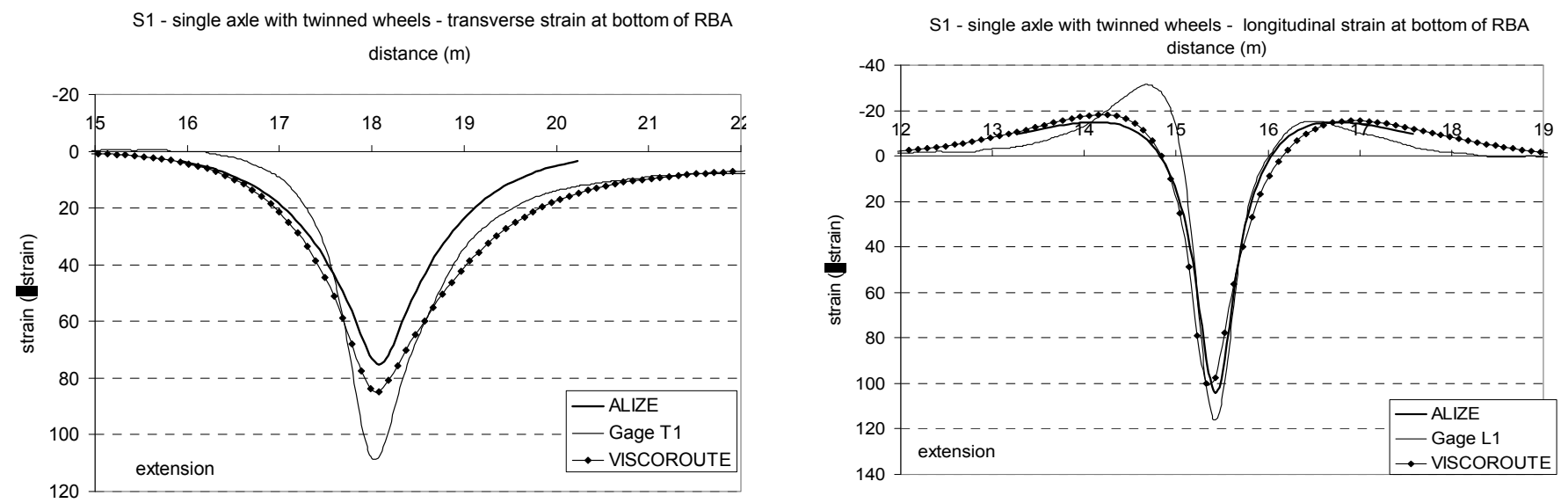

Figure 16. Structure 1 - comparison of measured and calculated strains under single axle with dual wheels.

$\mathrm{S} 1$ - tandem axle with single wheels- transverse strains at bottom of RBA distance $(\mathrm{m})$

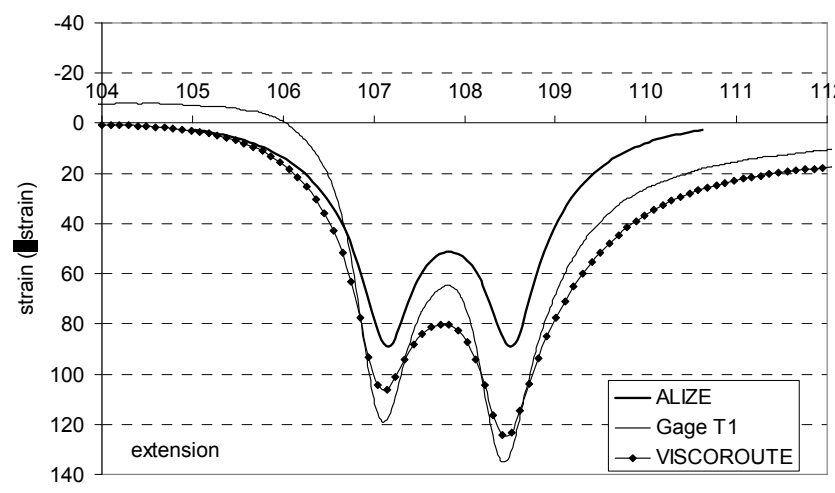

S1 - tandem axle with single wheels - longitudinalstrains at bottom of RBA

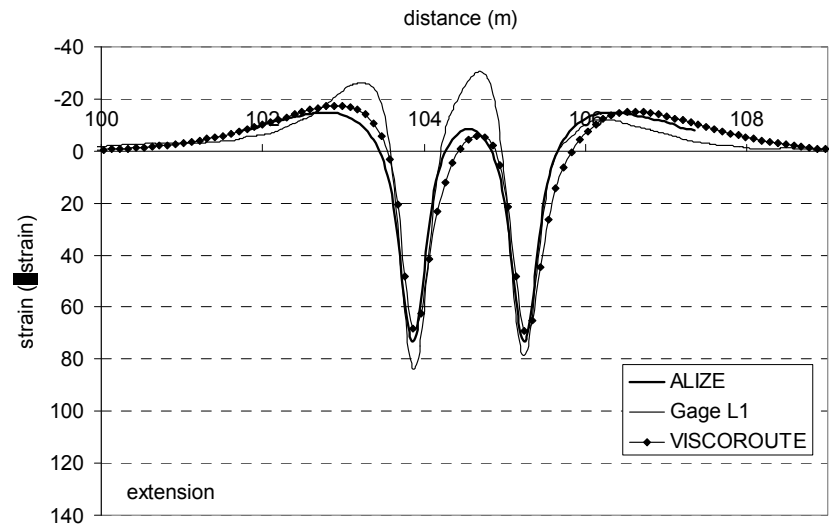

Figure 17. Structure 1 - comparison of measured and calculated strains under tandem axle with single wheels.

A difference can be observed between the dual wheel load at maximum measured longitudinal strains, and the loads with single wheels $(1,2$ or 3 axles) at maximum transverse strains.

The following conclusions can be made concerning the prediction of the maximum tensile strains, for all the load types:

- The linear elastic model (ALIZE) predicts the longitudinal strains reasonably well (about 10\% difference), but the transverse strains are strongly underestimated (about 50\% difference).
- The viscoelastic calculations (VISCOROUTEC 2.0) predict much higher transverse strains than ALIZE, but better predict the experimental transverse strains (about 10 to $15 \%$ difference with the experimental values). The predictions are particularly accurate for the tandem and tridem axles (Figures 15 and 17).

It appears, therefore, that visco-elasticity affects transverse strains more than longitudinal strains, which has already been observed on the experimental measurements. Viscous effects tend to in- 
crease the transverse strains, compared with linear elastic behaviour, and is confirmed both by the experimental measurements, and the VISCOROUTEC 2.0 calculations. The increase of transverse strains is particularly important for the tandem and tridem axle loads. This result can have important implications on classical pavement design calculations, carried out with linear elastic models. It implies that these calculations can significantly underestimate the real maximum tensile strains (this is discussed in the next section).

The results show that the VISCOROUTEC 2.0 software, based on the Huet-Sayegh model, simulates the response of the bituminous pavement reasonably well, for the conditions of the tests (temperature $20^{\circ} \mathrm{C}$ and speed $42 \mathrm{~km} / \mathrm{h}$ ), and the effects of different single or multiple axle loads. These satisfactory results were obtained with model parameters obtained from laboratory complex modulus tests. More detailed evaluations comparing VISCOROUTEC 2.0 with results from this APT experiment are planned, specifically different speed and temperature conditions (measurements are available for temperatures between 10 and $40^{\circ} \mathrm{C}$, and speeds from 3 to $70 \mathrm{~km} / \mathrm{h}$ ).

\section{EVALUATION OF THE AGGRESSIVENESS OF THE DIFFERENT AXLE COMBINATIONS}

The French pavement design method (SETRALCPC 1994, Corté \& Goux 1996) is a mechanisticempirical method, based on multi-layer linear elastic calculations. For bituminous pavements, such as those tested in this APT experiment, the main design criterion is based on the maximum tensile strain at the bottom of the bituminous layers. A second criterion, based on the maximum vertical strain at the top of the subgrade also exists. The tensile strain criterion is based on a fatigue law, for bituminous materials, determined experimentally from two point bending fatigue tests on trapezoidal specimens (standard EN 12697-24). The expression of the fatigue law is:

$$
\varepsilon=\varepsilon_{6}\left(\frac{N}{10^{6}}\right)^{b}
$$

Where:

$-\varepsilon_{6}$ is the strain leading to fatigue failure for $10^{6}$ load cycles;

$-\mathrm{b}$ is the exponent of the fatigue law; $\mathrm{b}=-0.2$ for bituminous materials;

- $\mathrm{N}$ is the number of load cycles.

Inverting the fatigue law (Equation 1) leads to the following expression, for the number of load cycles $\mathrm{N}_{\text {failure }}$ leading to failure:

$$
N_{\text {failure }}=10^{6}\left(\frac{\varepsilon}{\varepsilon_{6}}\right)^{-5}
$$

Using Equation 2, the relative aggressiveness A of two different loads, according to the French pavement design method, can be expressed, for bituminous pavements, by:

$$
A=\frac{N_{\text {failure }}(\operatorname{load} 2)}{N_{\text {failure }}(\operatorname{load} 1)}=\left[\frac{\varepsilon(\operatorname{load} 1)}{\varepsilon(\operatorname{load} 2)}\right]^{5}
$$

$A$ is defined as the ratio of the design lives (in terms of number of cycles leading to failure) for each load level, or as the ratio of the fatigue damage produced by one application of Load-2, in comparison with one application of Load-1. In the case of multiple axles groups, the coefficient $A$ is calculated for each individual axle of the group.

Values of the relative aggressiveness $A$ were determined for the different multiple axle loads, compared to the reference single wheel loaded at $42.5 \mathrm{kN}$. These values were calculated first using the maximum tensile strains $\varepsilon_{\text {tmax }}$ obtained with the design software ALIZE, and also using maximum tensile strains measured experimentally on the test track. The results are presented in Table 8.

Table 8. Relative aggressiveness coefficients obtained for the different multiple axle loads, in comparison with the single wheel loaded at $42.5 \mathrm{kN}$

\begin{tabular}{lcccc}
\hline Parameter & $\begin{array}{c}42.5 \mathrm{kN} \\
\text { single }\end{array}$ & $\begin{array}{c}42.5 \mathrm{kN} \\
\text { tandem } \\
\text { single }\end{array}$ & $\begin{array}{c}42.5 \mathrm{kN} \\
\text { tridem } \\
\text { single }\end{array}$ & $\begin{array}{c}65 \mathrm{kN} \\
\text { dual }\end{array}$ \\
\hline Measured & & & & \\
\hline$\varepsilon_{\text {tmax }}(\mu$ strain) & 115.9 & 135.1 & 144.7 & 116.2 \\
A value & - & 2.15 & 3.03 & 1.01 \\
\hline ALIZE calculations $(\mu$ strain) & & & \\
\hline$\varepsilon_{\text {tmax }}(\mu$ strain) & 83.6 & 88.6 & 97.3 & 104.2 \\
A value & - & 1.34 & 2.14 & 3.01 \\
\hline
\end{tabular}

With the ALIZE calculations, the most aggressive load is the single axle with dual wheels $(A=3.01)$, followed by the tridem axle $(A=2.14)$. With the experimental measurements, the rating is quite different, with the most aggressive load being the tridem axle $(A=3.03)$, and the least aggressive the single axle with dual wheels $(A=1.01)$. In conclusion, the standard linear elastic calculations again do not correctly predict the maximum tensile strains under multiple load configurations (due in particular to visco-elasticity), and can give misleading conclusions, concerning the aggressiveness of different axle configurations. In particular, it appears that the aggressiveness of tridem axles is underestimated by linear elastic calculations. The results obtained with VISCOROUTEC 2.0 suggest that aggressiveness can be better evaluated using viscoelastic models.

For a given load type, there was also a large difference between the experimental and calculated 
maximum tensile strains. (up to 50\%). However, it appears quite difficult to compare directly, for one load type, the aggressiveness obtained with experimental and calculated strains, because in the French design method, calibration coefficients are introduced to correct the calculated fatigue life, in order to match the field behaviour. Therefore, it is probable that these "calibration coefficients" already account for the difference between experimental and calculated strains. Consequently, only relative comparisons of damage caused by different axle configurations can be made, and not direct comparisons of damage due to the calculated and experimental strains.

\section{DISCUSSION OF THE IMPACT OF AXLE WHEELBASE AND 10\% INCREASE OF THE GROSS HEAVY VEHICLE WEIGHT}

In France, measures have recently been taken to relax gross weight legislation for $210 \mathrm{kN}$ tandem axles with dual wheels and $255 \mathrm{kN}$ tridem axles with single wheels, and to authorize an increase of $10 \%$ of the gross weight. On the IFSTTAR test track, both axle systems were tested with a wheel base of $1.38 \mathrm{~m}$. However, wheel base can vary depending on vehicle type. Table 9 presents the usual wheelbases used on heavy truck rear axle systems in France.

Table 9. Typical wheelbases used on heavy truck rear axle systems

\begin{tabular}{lcccc}
\hline & $\begin{array}{c}\text { Tridem, } \\
\text { single }\end{array}$ & $\begin{array}{c}\text { Tandem, } \\
\text { dual }\end{array}$ & $\begin{array}{c}\text { Tandem, } \\
\text { single }\end{array}$ & $\begin{array}{c}\text { Tandem, } \\
\text { single, } \\
\text { very wide }\end{array}$ \\
\hline Tires & $385 / 65$ & 1200 & $385 / 65$ & $445 / 65$ \\
& R22.5 & R20 & R22.5 & R22.5 \\
\hline Wheel & 135 & 135 & 130 & 130 \\
base & 130 & 130 & - & - \\
$(\mathrm{cm})$ & 120 & - & - & - \\
& 116 & - & - & - \\
& 112 & - & - & \\
\hline
\end{tabular}

Table 9 shows that tridem rear axle systems in particular can have smaller wheelbases than $1.38 \mathrm{~m}$, down to $1.12 \mathrm{~m}$. These small wheelbases are often used on vehicles carrying heavy materials, like cereals or aggregates, which need to manoeuvre easily and discharge their load at the rear of the vehicle (Figure 18). Particular concerns are being raised about the possible increase of the gross weight on these vehicles, because they are usually loaded to the maximum authorized load. It is therefore interesting to evaluate the aggressiveness of these tridem axles with small wheelbase. For this purpose, calculations were performed using both standard linear elastic and visco-elastic models (to try to take into account the visco-elastic effects), for pavement Structure 1 from the APT experiment. Three cases were considered:

1 The tridem axle with $1.38 \mathrm{~m}$ wheelbase with $3 \times 42.5 \mathrm{kN}$ load.

2 The tridem axle with $1.12 \mathrm{~m}$ wheelbase with $3 \times 42.5 \mathrm{kN}$ load.

3 The tridem axle with $1.12 \mathrm{~m}$ wheelbase with $3 \times 46.75 \mathrm{kN}$ load $(10 \%$ overload)

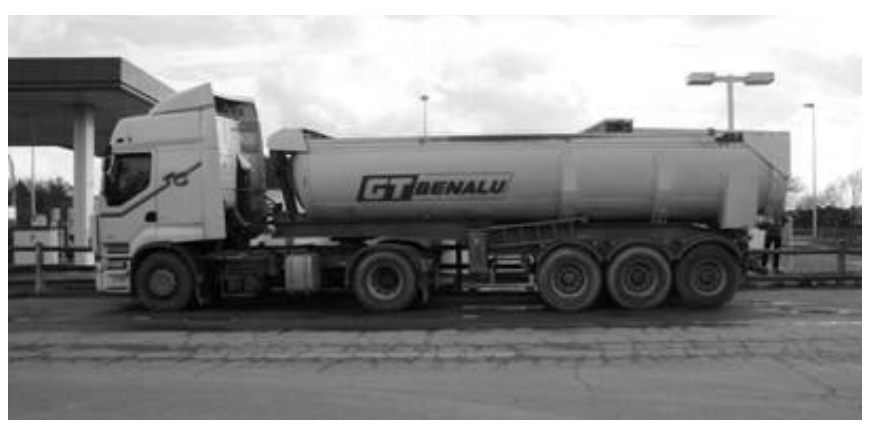

Figure 18. 44 ton heavy vehicle with tridem rear axle system, wheelbase $=112 \mathrm{~cm}$.

The results are presented in Table 10. The first case was considered as the reference, and the relative aggressiveness of cases 2 and 3, compared with this reference was calculated. For the linear elastic calculations, the results indicate:

- Relative aggressiveness $A$ of 1,56 for the tridem axle with $1.12 \mathrm{~m}$ wheelbase

- Relative aggressiveness $A$ of 2,51 for the tridem with $1.12 \mathrm{~m}$ wheelbase and $10 \%$ overload.

Table 10. Prediction of aggressiveness with reduced wheelbase and $10 \%$ overload.

\begin{tabular}{lccc}
\hline Parameter & $\begin{array}{l}42.5 \mathrm{kN} \\
\text { tridem, } \\
1.38 \mathrm{~m} \\
\text { wheelbase }\end{array}$ & $\begin{array}{l}42.5 \mathrm{kN} \\
\text { tridem, } \\
1.12 \mathrm{~m} \\
\text { wheelbase }\end{array}$ & $\begin{array}{l}46.75 \mathrm{kN} \\
\text { tridem, } \\
1.12 \mathrm{~m} \\
\text { Wheelbase }\end{array}$ \\
\hline ALIZE & & & \\
\hline$\varepsilon_{\text {tmax }}(\mu$ strain) & 97,3 & 106,4 & 117 \\
A value & 1 & 1,56 & 2,51 \\
VISCOROUTE & & & \\
$\varepsilon_{\text {tmax }}(\mu$ strain) & 132,5 & 146,4 & 161,3 \\
A value & 1 & 1,65 & 2,67 \\
\hline
\end{tabular}

With the viscoelastic calculations, the values of $A$ are slightly higher than for linear elasticity, but the difference is not significant $(A=2,67$ for case 3 instead of 2.51). There is, again, a large difference between the maximum tensile strains given by the linear elastic and visco-elastic calculations. However, a direct comparison between aggressiveness obtained with linear elastic or visco-elastic behaviour, for the same load, is not possible, because the design life calculations are calibrated only for the linear elastic model.

This last comparison is based only on model predictions, because these modified wheelbases and axle loads have not been tested on the accelerated test track. More APT tests clearly need to be carried out to improve understanding of the ag- 
gressiveness of different loads, including the effects of wheelbase, type of tires, loads and pavement structure, and to take into account the results in pavement design.

\section{CONCLUSIONS}

This paper presents the first pavement mechanics study carried out using the IFSTTAR's pavement circular test track with different axle system combinations mounted on each of its four arms.

The French road carriers' federation is currently exercising pressure on the government to increase the gross vehicle weight from $400 \mathrm{kN}$ to $440 \mathrm{kN}$ and more, without modifying the number of axles. Knowledge of the impact that such an increase may have on pavements is in great demand by society and the legislature.

The key finding from this study, as regards pavement mechanics, is that experimental strain measurements in pavement layers appear to provide the best information on the aggressiveness of an axle system. The results of the study concern mainly the tensile strains obtained at the bottom of bituminous layers, which are presently used as design criterion in the French and many other pavement design methods for bituminous pavements. The study has led to several interesting conclusions:

- Strain distributions under multiple axle loads are complex, and for the different axle combinations studied, the most critical tensile strains can be either longitudinal (for the dual wheels) or transverse (for the configurations with 1, 2 or 3 axles with single wheels).

- Visco- elastic behaviour seems to have a particularly strong effect on the transverse strains, which tend to cumulate under the passage of several successive axles, and return more slowly to zero than the longitudinal strains.

- Due to this accumulation of transverse strains, tandem and tridem axles produce, experimentally, higher tensile strains than what would be expected from linear elastic response.

- Comparisons with linear elastic calculations indicate that linear elasticity predicst longitudinal strains reasonably well, but underpredicts the transverse strains, in particular under tandem or tridem axles with single wheels. If linear elasticity is used for pavement design calculations, the aggressiveness of certain axle combinations may be underestimated. In particular, linear elasticity indicates the highest aggressiveness for single axles with dual wheels loaded at $65 \mathrm{kN}$, whereas strain measurements indicate that the tridem with single wheels $(42.5 \mathrm{kN}$ per wheel) produces higher tensile strains, and is therefore more aggressive.
- Better predictions of the measured strains (essentially the transverse strains) were obtained with the software VISCOROUTEC 2.0, using the visco-elastic Huet Sayegh Model. Viscoelastic calculations appear particularly interesting for predicting the effects of multiple axle loads. They give the same ratios between longitudinal and transverse strains to those recorded in the experimental measurements, whereas linear elastic calculations can give the opposite.

Based on these results in this study, prediction of response of bituminous pavements using viscoelastic models clearly appears to be very promising, but further studies are still needed to confirm and validate these results for a larger range of experimental conditions, including for instance higher temperatures. Application of such calculations to design requires caution, because in the French design method, the failure criteria, material specifications, and the associated calibration coefficients are based on linear elastic modelling, and changing the pavement model is not possible without also adjusting the other elements.

The results obtained from this study are limited, because they were obtained for a given set of axle combinations, with identical tires. Other aspects such as load, tire type, tire pressure, and wheelbase were not studied. However, they show that APT tests have a great potential for studying the effects of aggressiveness of different axle systems, which represent a very important issue for the transportation sector, because they can influence the evolution of heavy vehicle configurations, and permitted vehicle weights.

It is also clear that experiments like the one presented here, centred on measurement of deformations under different loads are not sufficient, and that to improve our understanding of axle system aggressiveness, it is necessary to undertake fatigue tests, until significant damage of the pavement structures is achieved. However, this implies some experimental constraints:

- Each load type must be tested on a separate pavement section (on the IFSTTAR facility, it is possible to carry simultaneous tests at two different radii, of $16 \mathrm{~m}$ and $19 \mathrm{~m}$ ).

- Since the acceleration capacity of the circular test track is limited (about 1 million loads per month), such tests can be performed only on relatively thin pavements $(15 \mathrm{~cm}$ of bituminous materials is approximately the maximum).

Another aspect which also needs to be investigated with accelerated testing is the effect of different axle configurations on the wear and deterioration of surface pavement layers. 


\section{ACKNOWLEDGMENTS}

The authors would like to thank Jean-Maurice Balay and Didier Bodin from IFSTTAR for their active participation in this project.

\section{REFERENCES}

Autret, P., de Boissoudy, A.B. \& Gramsammer, J.C. 1987. The circular test track of the Laboratoire Central des Ponts et Chaussées - First Results. Proc. 6th Intern. Conf. on Structural Design of Asphalt Pavements, Ann Arbor, June 13-17 1997. 1: 550-561.

Chabot, A., Chupin, O., Deloffre, L., Duhamel, D. 2010. Viscoroute 2.0: a tool for the simulation of moving load effects on asphalt pavement. IJRMPD Special Issue on Recent Advances in Numerical Simulation of Pavements 11(2): 227-250.

Chailleux, E., Ramond, G., Such, C., de la Roche, C. 2006. A mathematical-based master-curve construction method applied to complex modulus of bituminous materials. Roads Materials and Pavement Design 7 (EATA Special Issue) :75-92.

Corte, J.F., Goux, M.T. 1996. Design of pavement structures: the French technical guide. Transport Research Report, 1539: 116-124.
Duhamel, D., Chabot, A., Tamagny, P., Harfouche, L. 2005. ViscoRoute: visco-elastic modeling for asphalt pavements. Bulletin des Laboratoires des Ponts et Chaussées (http://www.lcpc.fr/en/sources/blpc/index.php), 258-259 : 89-103.

Gramsammer, J.C., Kerzreho, J.P., Odeon, H. 1999. The LCPC's A.P.T. Facility: Evaluation of Fifteen Years of Experimentations. Proceedings of 1rst International Conference on Accelerated Pavement Testing, October 18-20, 1999 Reno, Nevada.

Huet, C. 1963. Etude par une méthode d'impédance du comportement viscoélastique des matériaux hydrocarbonés. Ph.D. thesis. Université de Paris, France.

Huet, C. 1999. Coupled size and boundary-condition effects in viscoelastic heterogeneous and composite bodies. Mechanics of Materials 31 : 787-829.

IFSTTAR. The Accelerated Load Testing Facility: http://www.lcpc.fr/en/presentation/moyens/manege/index .dml

IFSTTAR : Alizé-Lcpc software for the design of pavements according to the French rational method : http://www.lcpc.fr/en/produits/alize/index.dml

Sayegh, G. 1965. Contribution à l'étude des propriétés viscoélastiques des bitumes purs et des bétons bitumineux. Ph.D. thesis Faculté des Sciences de Paris, France.

SETRA-LCPC 1994. Conception et dimensionnement des structures de chaussée. Guide Technique. Ministère de l'équipement des Transport et du Tourisme. Paris, France. 